DOI: 10.26693/JMBS05.03.052

УдК 669.01/.09

\title{
Єфременко В.Г.
}

\section{БІОРОЗЧИННІ СПЛАВИ ДЛЯ ВИКОРИСТАННЯ В ІМПЛАНТОЛОГІї}

\author{
ДВНЗ «Приазовський державний технічний університет», Маріуполь, Україна
}

vgefremenko@gmail.com

В оглядовій статті описано сучасні напрямки розвитку деяких груп металевих біоматералів, що застосовуються в імплантології для виготовлення біорозчинних (тимчасових) імплантів. До таких матеріалів висувають вимоги з біосумісності, міцності та швидкості біодеградації (розчинення) в фрізіологічному середовищі. Показано, що біорозчинні металеві матеріали поділяються на сплави на основі магнію, сплави на основі заліза та сплави на основі цинку. Ці сплави можуть мати суттєві переваги, оскільки магній, залізо і цинк входять до числа елементів, життєво важливих для діяльності організму людини, отже їх розчинення в тілі пацієнта $є$ потенційно безпечним для здоров'я при виведенні надлишку $з$ організму. Кожен $з$ перерахованих металів має власні недоліки, пов'язані із певними фрізикохімічними властивостями; усунення цих недоліків ставлять на меті при розробці відповідних сплавів 3 поліпшеними характеристиками. Магній має занадто високу швидкість розчинення та нестабільність механічних властивостей, які покращують за рахунок легування (розробкою сплавів Mg-Y-P3M-Zr, $\mathrm{Mg}-\mathrm{Al}-\mathrm{Zn}, \mathrm{Mg}-\mathrm{Al}-\mathrm{Zn}-\mathrm{Mn}, \mathrm{Mg}-\mathrm{Li}-\mathrm{Al}-\mathrm{P} 3 \mathrm{M}-\mathrm{Mn}$, тощо) та нанесення різноманітних захисних покриттів (гідроксиапатит, біополімери, тощо). Наразі розроблено та апробовано перші торгові марки імплантів, виготовлених з магнієвих сплавів. Для заліза характерним $є$ занадто низька швидкість біодеградації. Підвищена корозійна стійкість заліза спричиняє його накопичення в організмі із віддаленим негативним ефектом. Швидкість біодеградації заліза підвищують легуванням, наприклад, введенням паладію (утворює інтерметаліди), або марганцю (викликає деформаційне утворення епсілонмартенситу). Встановлено, що цинк має прийнятну швидкість біодеградації, але відрізняється низькими механічними властивостями. Для їх підвищення до цинку вводять легуючі елементи (Zn-Mg, Zn-Fe, Zn-Ca, Zn-Sr, Zn-Al, Zn-Cu, Zn-Al-Mg-Bi, Zn-Li, $\mathrm{Zn}-\mathrm{Ag}$ ) та застосовують термічну обробку і холодну пластичну деформацію. У статті описано основні технологічні підходи до покращення комплексу властивостей металевих матеріалів для біорозчинних імплантів.
Ключові слова: біорозчинний імплант, магній, залізо, цинк, сплав, біодеградація, міцність.

Зв'язок роботи 3 науковими програмами, планами, темами. Наукова робота проведена у рамках проекту ДВНЗ «Приазовського державного технічного університету», № держ. реєстрації $0119 U 103473$.

Вступ. Традиційні металеві матеріали, що використовуються для виготовлення штучних імплантів, складають три основні групи сплавів, а саме: нержавіючі сталі, сплави на титановій основі та сплави на основі Co-Cr. Перелічені сплави мають високу біосумісність, головним чином завдяки високій корозійній стійкості, що запобігає вивільненню іонів металів, які мають потенційну токсичність по відношенню до організму (Co, $\mathrm{Cr}, \mathrm{Ni}, \mathrm{Mo})$. Основні вимоги до імплантів, виготовлених з цих матеріалів, полягають в забезпеченні високій експлуатаційній надійності та довговічності задля подовження терміну використання імпланту та запобігання необхідності проведення повторних операцій для його заміни.

Проте існує різновид імплантів у вигляді фріксуючих конструкцій, які не призначені для тривалого використання: після досягнення певного результату в лікуванні вони видаляються з тіла пацієнта. Видалення тимчасового імпланту пов'язане із небажаним оперативним втручанням, оскільки воно $є$ травматичним та несе ризики ускладнення. В зв'язку з цим в останні десятиріччя активно розвивається новий напрям в біоінженерному матеріалознавстві, який полягає в розробці біорозчинних (biogradable) матеріалів для виготовлення тимчасових імплантів [1, 2]. Ідея застосування цих матеріалів полягає в тому, що імплант не виймається 3 тіла пацієнта після виконання певних завдань, а залишається в ньому, поступово деградуючи (розчиняючись) за рахунок хімічної взаємодії із внутрішнім середовищем тіла. Розробка біорозчинних металевих матеріалів наразі являє собою амбітну наукову задачу, яка привертає до себе пильну увагу матеріалознавців різних країн. 3 огляду на проблеми, які при цьому виникають, розробка 
ведеться по кількох напрямках, які наразі активно розвиваються [3].

Метою даної роботи був огляд результатів опублікованих наукових досліджень з розробки металевих біорозчинних матеріалів для штучних імплантів та аналіз сучасних тенденцій в цій сфрері.

\section{Сплави на основі магнію}

Суттєвим недоліком металевих біоматералів на основі заліза, титану, кобальту, які використовують в ортопедії, є їх висока міцність, яка набагато перевищує міцність кісток. При використання металевих імплантів може розвиватися ефект «стресекранування» («stress-shielding»), коли зовнішні навантаження припадають головним чином на імплант, а кістка виявляється слабо навантаженою. Це призводить до зменшення щільності кістки після іії зростання з повторним руйнуванням [1].

Окрім міцних матеріалів все більше застосування в імплантології знаходять кальцийфосфратна кераміка і біорозчинні полімери: полігліколева (PGA) і полімолочна (PLLA, PDLA) кислоти, їх сополімери (PLGA), гидроксіпохідні алканових кислот (РНA) [4]. Недоліками цих матеріалів $є$ низька і нестабільна міцність (опір міцності - 20-70 МПа, модуль Юнга - 1,2-6,9 ГПа), що унеможливлює виготовлення з них імплантів, які сприймають навантаження.

Альтернативою міцним металевим біоматеріалам, з одного боку, і неміцним біополімерам - 3 іншого, виступають сплави на основі магнію. Магній

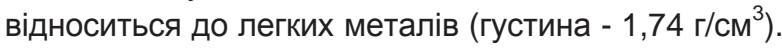
Його модуль Юнга і опір міцності становлять 41-45 ГПа і 113 МПа, відповідно, що вище, аніж у полімерів, та є максимально наближеним до механічних властивостей кісткової тканини людини (3-20 ГПа та 30-150 МПа, відповідно), порівняно з іншими металевими біоматеріалами.

У роботі [5] повідомляється про добру біосумісність магнію та продуктів його корозії. Магній $є$ важливим для процесів метаболізму людського організму як кофрактор утворення біля трьохсот фрерментів [3]. Продуктами корозії магнію в організмі $є$ його іони $\mathrm{Mg}^{2+}$, гідроксид-іони $\mathrm{OH}^{-}$і водень $\left(\mathrm{H}_{2}\right)$. Іони $\mathrm{Mg}^{2+}$ сприяють швидкому загоєнню травмованих тканин, не викликаючи при цьому клітинної токсичності; їх надлишок виводиться з організму через січові шляхи. Магнієві сплави легко розчиняються в воді та в інших корозійноактивних середовищах, що робить їх потенційно привабливими біорозчинними матеріалами. Перше застосування магнієвих сплавів в якості імплантів відносять до кінця 19 сторіччя [3].

До недоліків чистого магнію відносять високу крихкість, виділення водню при розчиненні магнію (водень накопичується біля імпланту та негативно впливає на фрормування кісткової тканини), небажане підвищення рівня лужності організму [6]. Тому постає питання про застосування не чистого магнію, а його сплавів із поліпшеними фрізико-хімічними властивостями і підвищеною стійкістю до корозії.

Проводяться дослідження можливості використання в якості біорозчинних матеріалів комерційних магнієвих сплавів різних систем легування, таких як WE43 (сплав системи Mg-Y-P3M-Zr), AZ91 (Mg-Al-Zn), AZ31 (Mg-Al-Zn-Mn), LAE442 (Mg-Li-Al-P3M-Mn) тощо [1, 7]. Наприклад, сплав AZ31 вміщує приблизно 2,5 \% Al, 0,9 \% Zn, 0,3 \% Mn, решта - Mg. Оскільки згадані сплави містять хімічні елементи з недоведеною біосумісністю, додатково розробляються магнієві сплави, що складаються з нетоксичних елементів, а саме сплави систем легування $\mathrm{Mg}-\mathrm{Zn}, \mathrm{Mg}-\mathrm{Zn}-\mathrm{Ca}$ та $\mathrm{Mg}-\mathrm{Ca}$ [8]. В останні роки на ринку з'явились комерційні біорозчинні шурупи, виготовлені з магнієвих сплавів: «Magnezixâ» фрірми Sintellix, «Milagroâ» фрірми DePuy Mitek (останній виготовлений зі сплаву Mg-Y-P3M-Zr) [3].

Однією з основних проблем для Mg-сплавів є висока швидкість розчинення в фрізіологічному середовищі, що унеможливлює їх використання по прямому призначенню. Швидка деградація імпланту призводить до утворення газових порожнин або розривів на межі розділу «кістка/імплант». У зв'язку з цим проводяться дослідження з підвищення корозійної стійкості магнієвих сплавів для біомедичного використання. Одним з напрямків $є$ нанесення захисних покриттів. До цих технологій відносяться: отримання шару $\mathrm{Al}_{2} \mathrm{O}_{3}$ застосуванням плазмової імплантації атомів (іонів) алюмінію і кисню [8], електрохімічне осадження шару фторованого гідроксиапатиту (FHA) і Ca-P покриття [9], імпульсне осадження гідроксиапатитового покриття з дефіцитом Ca [10], утворення композитного покриття « $\mathrm{CaHPO}_{4} \times 2 \mathrm{H}_{2} \mathrm{O} /$ полікапролактон» [12], осадження гідроксиапатиту методом анодного розчинення магнію [1], тощо. Для захисту магнієвих сплавів від корозії використовують вище перераховані біорозчинні полімери, а також силанові покриття [5].

Останні дослідження виявили потенційно високу біосумісність графену та його похідних в якості захисного покриття на магнієвих сплавах. Повідомлялося, що ці покриття сприяють адгезії та розмноженню людських клітин-остеобластів та полегшують диференціювання мезенхімальних стромальних клітин в остеобласти [12]. У роботі [13] повідомляється про утворення комплексного покриття «оксид графену/гідроксиапатит», в якому первинно нанесений оксид графену при витримці в рідині, що симулює людське тіло, стимулював відкладення 
гідроксиапатиту. Таке покриття значно підвищило корозійну стійкість магнієвого сплаву AZ91.

Іншим напрямом $€$ підвищення фрізико-хімічних властивостей $\mathrm{Mg}$-сплавів додаванням легуючих елементів, наприклад паладію [14]. В роботі [6] показано, що введення 0,1 \% скандію знижує швидкість розчинення стандартного сплаву МЛ-10 у фрізіологічному розчині (Венофундин), в той час як додавання 0,05 \% срібла підвищує її. Встановлено, що введення 1,25-1,3 \% Zr i 2,9-3,1 \% Nd забезпечує підвищення стабільності механічних властивостей магнієвого сплаву при тривалій витримці в фрізіологічному розчині (Гелофузин) [15]. В цій же роботі доведено відсутність токсичного впливу продуктів деградації сплаву $\mathrm{Mg}-\mathrm{Zr}-\mathrm{Nd}$ на живий організм та встановлено позитивну динаміку репаративного остеогенезу.

\section{Сплави на основі заліза}

Чисте залізо та сплави на основі заліза були запропоновані до використання в якості біорозчинних матеріалів на початку 2000-х років [17]. Ці сплави мають більш високу міцність і модуль Юнга порівняно із магнієвими сплавами. Втім, імплантам, виробленим із заліза, потрібні роки для повного розчинення, тобто швидкість їх корозії занадто мала, щоб імплантат зник без тривалих побічних есректів. Продукти окислення заліза (іони $\mathrm{Fe}^{2+}$ та $\left.\mathrm{Fe}^{3+}\right) €$ важливими для життєдіяльності та не проявляють токсичності в очікуваних концентраціях [17]. Однак через дуже низьку біодеградацію чистого $\mathrm{Fe}$, такі стенти виявляють негативні реакції, пов'язані із накопиченням нерозчинного гидроксиду заліза переважно в клітинах в місці імплантації. В подальшому спостерігається міграція пересичених залізом клітин по всьому організму, викликає хронічні запалення [18].

Для збільшення швидкість біодеградації заліза були розроблені $\mathrm{Fe}-\mathrm{Mn}$ сплави, в яких використовується деформаційне утворення епсілонмартенситу. Епсілон-мартенсит ділянки якого розподілені в структурі аустеніту, підвищує механічні властивості та прискорює швидкість корозії сплаву [19]. Проте швидкість біодеградації залишається на порядок нижчою у порівнянні зі сплавами на основі Mg. Легування $\mathrm{Fe}-\mathrm{Mn}$ сплавів паладієм у поєднанні з термічною обробкою додатково підвищує міцність та швидкість корозії завдяки виділенню включень інтерметаліду (Fe, Mn)Pd [20].

\section{Сплави на основі цинку}

Перші данні відносно використання цинкових сплавів для біорозчинних імплантів з'явилися впродовж останніх кількох років [3]. Подібно до магнію та заліза, цинк $є$ життєво важливим мікроелементом в організмі людини, входячи до складу багатьох ферментів і інших білків, забезпечуючи опти- мальний перебіг обмінних процесів, а також ріст, поділ та функціонування клітин [22]. 3 цих позицій іони цинку, що виділяються з імпланту при деградації, можуть нормально інтегруватися в метаболічну активність організму, не викликаючи токсичних ефректів.

Електродний потенціал цинку $(-0,762$ В) $€$ проміжним між магнієм $(-2,372$ В) та залізом $(-0,444 \mathrm{~B})$, отже чистий цинк кородує із сприятливою кінетикою, тобто швидше, ніж залізо, але повільніше за магнієві сплави. Це пов'язано із утворенням пасивуючих шарів на поверхні [22]. Продукти розпаду цинкового сплаву (іони $\mathrm{Zn}^{2+}$ ) вважаються достатньо біосумісними і навіть такими, що спричиняють протизапальну дію [23]. Сплави на основі цинку мають високу технологічність при виготовленні та обробленні; на відміну від магнієвих сплавів їх можна виплавляти в атмосфері повітря.

В роботі [24] показано можливість контролювати швидкість біодеградації чистого цинку введенням заліза. Добавка 1,3 \% заліза вдвічі прискорила корозію цинку внаслідок мікрогальванічного ефекту, викликаного утворенню дельта-фрази ( $\left.\mathrm{Zn}_{11} \mathrm{Fe}\right)$. Гістологічні дослідження, проведені по закінченню 14 тижнів після введення імпланту щуру, показали відсутність небажаних системних ефектів в тканинах, безпосередньо прилеглих до імпланту.

Використання імплантів із цинку стримується його низькими механічними властивостями (опір міцності $\left(\sigma_{\mathrm{B}}\right)-50-140 \mathrm{MПа,} \mathrm{відносне} \mathrm{подовження}$ $(\delta)-0,3-5,8$ \%) [21]. Наразі активно розробляються цинкові сплави з більш високим комплексом властивостей. Основним напрямком є введення легуючих елементів, що забезпечують твердорозчинне зміцнення, а також утворення зміцнювальних інтерметалідних фраз. В цьому напрямку розроблені сплави різних систем легування: Zn-Mg, Zn-Ca, Zn-Sr, Zn-Al, Zn-Cu, Zn-Al-Mg-Bi, Zn-Li, Zn-Ag, тощо [21]. В двох останніх випадках підвищення міцності забезпечується інтерметалідними з'єднаннями $\alpha-\mathrm{LiZn}_{4}$ [25] і $\varepsilon-A g Z \mathrm{n}_{3}$, відповідно. Наразі досягнуто такі властивості цинкових сплавів: Zn-5Al $\left(\sigma_{\mathrm{B}}=300, \quad \delta=16 \%\right), \quad \mathrm{Zn}-4 \mathrm{Li} \quad\left(\sigma_{\mathrm{B}}=440, \quad \delta=13,7 \%\right)$, $\mathrm{Zn}-7 \mathrm{Ag}\left(\sigma_{\mathrm{B}}=287, \delta=32 \%\right)[21,26]$. Ресурсом підвищення механічних властивостей $є$ термічна обробка, а також холодна пластична деформація.

Заключення. Створення біорозчинних металевих матеріалів для тимчасових імплантів ведеться в напрямках розробки сплавів на основі магнію, на основі заліза та на основі цинку. Ці елементи є важливим для життєдіяльності людини, отже їх розчинення в тілі пацієнта $€$ потенційно безпечним для здоров'я людини. Недоліком сплавів магнію та заліза є їх відповідно висока та низька швидкість 
біодеградації у фрізіологічних рідинах. Сплави на основі цинку займають проміжну позицію за стійкістю до біодеградації і в цьому сенсі $є$ найбільш перспективним класом матеріалів, втім, вони мають знижений рівень міцності. Для підвищення комплексу механічних та фрізико-хімічних властивостей сплавів всіх трьох груп використовують легування, термічну обробку, а також нанесення захисних покриттів.

Перспективи подальших досліджень в цьому напрямку полягають у проведенні тривалих клінічних досліджень і аналізі їх результатів для доведення безпечності для людини розроблених біорозчинних матеріалів на основі магнію, заліза і цинку.

\section{References}

1. Niinomi M, Nakai M, Hieda J. Development of new metallic alloys for biomedical applications. Acta Biomater. 2012; 8: 3888-903. PMID: 22765961. DOI: 10.1016/j.actbio.2012.06.037

2. Ibrahim MZ, Sarhan AAD, Farazila Y, Hamdi M. Biomedical materials and techniques to improve the tribological, mechanical and biomedical properties of orthopedic implants - A review article. J Alloys Compd. 2017; 15: 636-7. DOI: 10.1016/j.jallcom.2017.04.231

3. Muhammad Imran Rahim, Sami Ullah, Mueller PP. Advances and challenges of biodegradable implant materials with a focus on magnesium-alloys and bacterial infections. Metals. 2018; 8(7): 532. DOI: 10.3390/met8070532

4. Chen C-H, Shyu VB-H, Chen Y-C, Liao H-T, Liao C-J, Chen C-T. Reinforced bioresorbable implants for craniomaxillofacial osteosynthesis in pigs. British Journal of Oral and Maxillofacial Surgery. 2013; 51(8): 948-52. DOI: 10.1016/ j.bjoms.2013.07.011

5. Chakraborty PB, Al-Saadi S, Choudhary L, Eslami Harandi S, Singh R. Magnesium Implants: Prospects and Challenges. Materials (Basel). 2019 Jan; 12(1): 136. PMID: 30609830. DOI: 10.3390/ma12010136

6. Chernyy VN, Yatsun EV, Golovakha ML, Shalomeev VA. Novyy rastvorimyy splav na osnove magniya dlya primeneniya $v$ travmatologii [New soluble magnesium-based alloy for use in traumatology]. Ortopediya, travmatologiya $i$ protezirovanie. 2016; 4: 26-33. [Russian]

7. Gu XN, Li N, Zhou WR, Zheng YF, Zhao X, Cai QZ, et al. Corrosion resistance and surface biocompatibility of a microarc oxidation coating on a Mg-Ca alloy. Acta Biomater. 2011; 7: 1880-9. PMID: 21145440. DOI: 10.1016/ j.actbio.2010.11.034

8. Kannan MB, Raman RKS. Evaluating the stress corrosion cracking susceptibility of Mg-Al-Zn alloy in modifiedsimulated body fluid for orthopaedic implant application. Scripta Mater. 2008; 59: 175-8. DOI: 10.1016/ j.scriptamat.2008.03.001

9. Li J, Song Y, Zhang S, Zhao C, Zhang F, Zhang X, et al. In vitro responses of human bone marrow stromal cell to a fluoridated hydroxyapatite coated biodegradable Mg-Zn alloy. Biomaterials. 2010; 31: 5782-8. PMID: 20452668. DOI: 10.1016/j.biomaterials.2010.04.023

10. Wang HX, Guan SK, Wang X, Ren CX, Wang LG. In vitro degradation and mechanical integrity of Mg-Zn-Ca alloy coated with Ca-deficient hydroxyapatite by the pulse electrodeposition process. Acta Biomater. 2010; 6: $1743-8$. PMID: 20004746. DOI: 10.1016/j.actbio.2009.12.009

11. Wang $\mathrm{H}$, Zhao $\mathrm{C}$, Chen $\mathrm{Y}$, Li J, Zhang X. Electrochemical property and in vitro degradation of DCPD-PCL composite coating on the biodegradable Mg-Zn alloy. Mater Lett. 2012; 68: 435-8. DOI: 10.1016/j.matlet.2011.11.029

12. Nayak TR, Andersen H, Makam VS, Khaw C, Bae S, Xu X, et al. Graphene for controlled and accelerated osteogenic differentiation of human mesenchymal stem cells. ACS Nano. 2011; 5: 4670-8. PMID: 21528849. DOI: 10.1021/ nn200500h

13. Gao F, Xu C, Hu H, Wang Q, Gao Y, Chen H, Guo Q, Chen D, Eder D. Biomimetic synthesis and characterization of hydroxyapatite/graphene oxide hybrid coating on Mg alloy with enhanced corrosion resistance. Mater Lett. 2015; 138: 25-8. PMID: 31658682. DOI: 10.3390/nano9101435

14. Gonzalez S, Pellicer E, Frnell J, Blanquer A, Barrios L. Improved mechanical performance and delayed corrosion phenomena in biodegradable Mg-Zn-Ca alloys through Pd-alloying. J Mech Behav Biomed Mater. 2012; 6: 53-62. PMID: 22301173. DOI: 10.1016/j.jmbbm.2011.09.014

15. Shalomeev V, Aikin N, Chorniy V, Naumik V. Design and examination of the new biosoluble casting alloy of the system $\mathrm{Mg}-\mathrm{Zr}-\mathrm{Nd}$ for osteosynthesis. Eastern-Evropian Journal of Enterprise Technologies, 2019; 1(12): 40-8. DOI: 10.15587/1729-4061.2019.157495

16. Peuster M, Wohlsein P, Brugmann M, Ehlerding M, Seidler K, Fink C, Brauer H, Fischer A, Hausdorf G. A novel approach to temporary stenting: Degradable cardiovascular stents produced from corrodible metal-results 6-18 months after implantation into New Zealand white rabbits. Heart. 2001; 86: 563-9. PMID: 11602554. DOI: 10.1136/ heart.86.5.563.

17. Fagali, N.S.; Grillo, C.A.; Puntarulo, S.; Fernandez Lorenzo de Mele, M.A. Cytotoxicity of corrosion products of degradable Fe-based stents: Relevance of pH and insoluble products. Colloids Surf B Biointerfaces. 2015; 128: 480-8. PMID: 25797480. DOI: 10.1016/j.colsurfb.2015.02.047. 
18. Mueller PP Arnold S Badar M Bormann D Bach FW Drynda A, Meyer-Lindenberg A, Hauser H, Peuster M. Histological and molecular evaluation of iron as degradable medical implant material in a murine animal model. $J$ Biomed Mater Res. A 2012; 100: 2881-9. PMID: 22623368. DOI. 10.1002/jbm.a.34223

19. Hermawan H, Dube D, Mantovani D. Degradable metallic biomaterials: design and development of Fe-Mn alloys for stents. J Biomed Mater Res A. 2010; 93:1-11. PMID: 19437432. DOI: 10.1002/jbm.a.32224

20. Schinhammer M, Hanzi AC, Luffler JF, Uggowitzer PJ. Design strategy for biodegradable Fe-based alloys for medical applications. Acta Biomater.2010; 6: 1705-13. PMID: 19654056. DOI: 10.1016/j.actbio.2009.07.039

21. Levy GK, Goldman J, Aghion E. The prospects of zinc as a ctructural material for biodegradable implants - A review paper metals. Metals. 2017; 7(10): 402. DOI: 10.3390/met7100402

22. Liu X, Sun J, Qiu K, Yang Y, Pu Z, Li L, Zheng Y. Effects of alloying elements (Ca and Sr) on microstructure, mechanical property and in vitro corrosion behavior of biodegradable $\mathrm{Zn}-1.5 \mathrm{Mg}$ alloy. J Alloys Compd. 2016; 664: 444-52. DOI: 10.1016/j.jallcom.2015.10.116

23. Bowen PK, Drelich J, Goldman J, Zinc exhibits ideal physiological corrosion behavior for bioabsorbable stents. Adv Mater. 2013; 25: 2577-82. DOI: 10.1002/adma.201300226

24. Kafri A, Ovadia S, Goldman J, Drelich J, Aghion Eli. The suitability of $\mathrm{Zn}-1.3 \% \mathrm{Fe}$ alloy as a biodegradable implant material. Metals. 2018; 8(3): 153. DOI: 10.3390/met8030153

25. Zhao S, Seitz J-M, Eifler R, Maier HJ, Guillory RJ, Earley EJ, Drelich A, Goldman J, Drelich JW. Zn-Li alloy after extrusion and drawing: Structural, mechanical characterization, and biodegradation in abdominal aorta of rat. Mater Sci Eng C. 2017; 76: 301-12. DOI:10.1016/j.msec.2017.02.167

26. Sikora-Jasinska M, Mostaed E, Mostaed A, Beanland R, Mantovani D, Vedani M. Fabrication, mechanical properties and in vitro degradation behavior of newly developed $\mathrm{ZnAg}$ alloys for degradable implant applications. Mater Sci Eng C. 2017; 77: 1170-81. DOI: 10.1016/j.msec.2017.04.023

\section{УДК 669.01/.09 \\ БИОРАСТВОРИМЫЕ СПЛАВЫ ДЛЯ ИСПОЛЬЗОВАНИЯ В ИМПЛАНТОЛОГИИ \\ Ефременко В.Г.}

Резюме. В обзорной статье описаны современные направления разработки некоторых групп металлических биоматералов для применения в имплантологии при изготовлении биорастворимых (временных) имплантов. К таким материалам выдвигают требования по биосовместимости, прочности и скорости биодеградации (растворения) в фризиологической среде.

Показано, что биорастворимые металлические материалы подразделяются на сплавы на основе магния, сплавы на основе железа и сплавы на основе цинка. Эти сплавы могут иметь существенные преимущества, поскольку магний, железо и цинк входят в число элементов, жизненно важных для деятельности организма человека, следовательно, их растворение в теле пациента потенциально безопасно для здоровья при выведении их избытка из организма.

Каждый из перечисленных металлов имеет собственные недостатки, связанные с определенными физико-химическими свойствами; устранение этих недостатков ставят целью при разработке соответствующих сплавов с улучшенными характеристиками. Магний имеет слишком высокую скорость растворения и нестабильность механических свойств, которые улучшают за счет легирования (разработкой сплавов Mg-Y-P3M-Zr, Mg-Al-Zn, Mg-Al-Zn-Mn, Mg-Li-Al-P3M-Mn и т.д.) и нанесения различных защитных покрытий (гидроксиапатит, биополимеры и т.д.). На данный момент уже разработаны и апробированы первые торговые марки имплантов, изготовленных из магниевых сплавов. Для железа характерна слишком низкая скорость биодеградации.

Повышенная коррозионная стойкость железа вызывает его накопление в организме с удаленным отрицательным эффектом. Скорость биодеградации железа повышают легированием, например, введением палладия (образует интерметаллиды), или марганца (вызывает деформационное образование эпсилон-мартенсита). Установлено, что цинк имеет приемлемую скорость биодеградации, но отличается низкими механическими свойствами. Для их повышения к цинку вводят легирующие элементы (Zn-Mg, Zn-Fe, Zn-Ca, Zn-Sr, Zn-Al, Zn-Cu, Zn-Al-Mg-Bi, Zn-Li, Zn-Ag) и применяют термическую обработку и холодную пластическую деформацию. В статье описаны основные технологические подходы к улучшению комплекса свойств металлических материалов для биорастворимых имплантов.

Ключевые слова: биорастворимый имплант, магний, железо, цинк, сплав, биодеградация, прочность. 


\section{UDC $669.01 / .09$}

\section{Biodegradable Alloys for Implantology}

\section{Efremenko V. G.}

Abstract. The review article describes the current trends in the development of some groups of metal biomaterials used in implantology for the manufacture of biodegradable (temporary) implants. The "biodegradation" concept is that implants are not intended for long-life application to be gradually dissolved in human body.

There are requirements for such materials which are biocompatibility, strength and rate of biodegradation (dissolution) in a physiological environment. It is shown that biodegradable metallic materials are divided into magnesium alloys, iron alloys and zinc alloys. These alloys can have significant benefits because magnesium, iron, and zinc are among the elements vital for human wellbeing, so dissolving them in patient body is potentially safe for health when removing excess from the body.

Each of the listed metals has its own disadvantages related to certain physical and chemical properties; the elimination of these disadvantages is aimed at the development of suitable alloys with improved performance. Magnesium has a very high dissolution rate and instability of mechanical properties that are improved by doping $(\mathrm{Mg}-\mathrm{Y}-\mathrm{REM}-\mathrm{Zr}, \mathrm{Mg}-\mathrm{Al}-\mathrm{Zn}, \mathrm{Mg}-\mathrm{Al}-\mathrm{Zn}-\mathrm{Mn}, \mathrm{Mg}-\mathrm{Li}-\mathrm{Al}-\mathrm{RZM}-\mathrm{Mn}$, etc.) and by deposition of different coatings with protective abilities such as ceramics $\left(\mathrm{Al}_{2} \mathrm{O}_{3}\right)$, hydroxyapatite, biodegradable polymers (PGA, PLLA, PDLA, PHA), sylane, graphene and its derivatives, composite "ceramics/biopolymer, etc.

Trademarks of implants made of $\mathrm{Mg}$-based alloys have already been developed and tested. The iron is characterized by too low biodegradation rate. Increased corrosion resistance of iron causes its accumulation in human body with a prolonged negative effect. The rate of iron biodegradation is increased by doping, for example, the introduction of palladium (forms intermetallides), or manganese (causes deformation of epsilonmartensite). Zinc has been found to have an acceptable rate of biodegradation, but it has low mechanical properties. To increase the properties, alloying elements $(\mathrm{Zn}-\mathrm{Mg}, \mathrm{Zn}-\mathrm{Fe}, \mathrm{Zn}-\mathrm{Ca}, \mathrm{Zn}-\mathrm{Sr}, \mathrm{Zn}-\mathrm{Al}, \mathrm{Zn}-\mathrm{Cu}$, $\mathrm{Zn}-\mathrm{Al}-\mathrm{Mg}-\mathrm{Bi}, \mathrm{Zn}-\mathrm{Li}, \mathrm{Zn}-\mathrm{Ag}$ ) are added into zinc; the proper heat treatment and cold plastic deformation are applied also. It is concluded that among the biodegradable materials only magnesium-based alloys are already commercialized to be widely proved in extended clinic trials. The article describes the main technological approaches to improving the complex properties of metallic materials for biodegradable implants.

Keywords: biodegradable implant, magnesium, iron, zinc, alloy, biodegradation, strength.

The authors of this study confirm that the research and publication of the results were not associated with any conflicts regarding commercial or financial relations, relations with organizations and/or individuals who may have been related to the study, and interrelations of coauthors of the article. 